\title{
Learning Management Model to Promote Growth Mindset of Student Teachers
}

\author{
Marut Patphol ${ }^{1}$, Jittirat Saengloetuthai ${ }^{2}$, Chamras Intalapaporn ${ }^{2}$ \\ ${ }^{1}$ Graduate School, Srinakharinwirot University, Bangkok, Thailand \\ ${ }^{2}$ Faculty of Education, Nakhon Pathom Rajabhat University, Nakhon Pathom, Thailand \\ Email: rutmarut@gmail.com
}

How to cite this paper: Patphol, M., Saengloetuthai, J., \& Intalapaporn, C. (2021). Learning Management Model to Promote Growth Mindset of Student Teachers. Open Journal of Social Sciences, 9, 396-408. https://doi.org/10.4236/jss.2021.95021

Received: April 20, 2021

Accepted: May 22, 2021

Published: May 25, 2021

Copyright $\odot 2021$ by author(s) and Scientific Research Publishing Inc. This work is licensed under the Creative Commons Attribution International License (CC BY 4.0).

http://creativecommons.org/licenses/by/4.0/

\begin{abstract}
This research aimed to develop the assessment of efficiency of a learning management model to promote growth mindset of student teachers. The samples consisted of 134 freshman student teachers at a university in Thailand. It is a quasi-experimental research. T-test for dependent sample was used for data analysis. The results revealed that the learning management model to promote growth mindset of student teachers was based on personalized learning, self-directed learning, internal coaching, authentic assessment, and reflection. There were 5 components of learning management, i.e., students as learning owners, activity design, creative learning, creative learning activity management, assessment for learning development, and creative feedbacks. Besides, growth mindset of student teachers in post-learning management was significantly higher than in pre-learning management $(p<0.01)$.
\end{abstract}

\section{Keywords}

Elementary Teacher Education, Instructional Practices, Student Teaching, Teacher Education Preparation

\section{Introduction}

Growth mindset is a personal belief that their own intelligence, success, and efficacy can be developed further and that they can learn and develop themselves to success as expected by practice and accumulated experiences, along with learning process with determination, perseverance, and effort. The definition of growth mindset is opposite to fixed mindset, that is, to believe that intelligence in different aspects is something inborn and cannot be developed and to believe that growth mindset is not an open mind or flexible belief without any reasons 
(Dweck, 2008; Dweck, 2012; Schroder, Moran, Donnellan, and Moser, 2014; Hanover Research, 2015; Rienzo, Rolfe, and Wilkinson, 2015; Education Week Research Center, 2016; Alerson, 2017; Silver and Stafford, 2017; Hildrew, 2018; Smith and Firth, 2018).

Growth mindset is useful to learners as a key factor of learning success because learners with growth mindset believe that they can learn all things if they try their best. With growth mindset, learners will put effort to do activities in accordance with their own learning approaches until success. Moreover, growth mindset also encourages will power of learners to show (Weiss and Fortus, 2013) of self-dependence rather than depending on others (Grant and Dweck, 2003); and to be able to manage their stress or anxiety caused by struggle on their own by problem-solving process and knowledge sharing with other others (Yeager and Dweck, 2012). It also encourages learners to learn challenges and other things they have not learned before, without scare of failures because they think failures always create learning and development, which are the key foundations of future innovation creation (Good, Anderson and Inzlicht, 2003; Blackwell, Trzesniewski, and Dweck, 2007; Dweck, 2008; Flores, Lemons, and McTernan, 2011; Dweck, 2012; Weiss and Fortus, 2013; Gregory and Kaufeldt, 2015; Rienzo, Rolfe, and Wilkinson, 2015; Alerson, 2017).

Learners with growth mindset have inner motivation with no need for extrinsic incentives. This is desirable learning among learners of this era, in which they can quickly access various learning sources by modern technology. Intrinsic motivation increases self-learning behavior, determination to put effort to achieve the goals, self-discipline, self-direction, self-regulation, self-control in learning (Dockterman and Blackwell, 2014), better enthusiasm, continual search for better things. It also increases desire for new challenging activities, no desire to do same things without development, and planning learning process based on their skills as well as desire (Mueller and Dweck, 1998; Good, Anderson, and Inzlicht, 2003; Grant and Dweck, 2003; Dweck, 2006; Blackwell, Trzesniewski, and Dweck, 2007; Dweck, 2008; Dweck, 2009; Dweck, 2012; Weiss and Fortus, 2013; Dockterman and Blackwell, 2014; Gregory and Kaufeldt, 2015; Rienzo, Rolfe, and Wilkinson, 2015; Stager, 2015; Alerson, 2017; Clark and Sousa, 2018; Ng, 2018).

To develop student teachers for having growth mindset is another key mission of educational management in the field of teaching profession. The objectives are to create their growth mindset in learning management and to develop learners as learning persons (Herbert-Smith, 2018; Brandman University, 2019; Gunn, 2020; Millersville University, 2020). According to previous studies on growth mindset development model, it was found that High Point University (2016) developed QEP Development Process to promote growth mindset of learners. The university was successful in this. However, so far, no results of research on learning management models to directly develop growth mindset of student teachers have been found yet. For this reason, it is interesting to find out 
how learning management models for effective growth mindset development of student teachers will be like. The objectives of this research were 1) to develop a learning management model to promote growth mindset of student teachers and 2) to assess efficiency of a learning management model to promote growth mindset of student teachers.

\section{Methodology}

For the development of the learning management model to promote growth mindset of student teachers, the researcher followed 4 steps of the methodology and development, i.e., 1) studying basic data, 2) drafted model development, 3) trial, and 4) effectiveness assessment; as per the below details.

\subsection{Step 1: Studying Basic Data}

The researcher studied basic data for the development of the learning management model to promote growth mindset of student teachers as follows. 1) Opinions from 5 experts in the development of growth mindset of student teachers were studied. A 5-point scale questionnaire with 10 questions was used. The reliability of the rating scale was 0.82 . 2) Desire of 10 student teachers for the development of growth mindset of student teachers was studied. A 5-point scale questionnaire with 10 questions was used. The reliability of the rating scale was 0.80. 3) Desire of 25 student teachers for the development of growth mindset of student teachers was studied. A 5-point scale questionnaire with 10 questions was used. The reliability of the rating scale was 0.84 . For the scoring criteria of the 3 questionnaires, 5 = highest, $4=$ high, 3 = moderate, $2=$ low, $1=$ lowest. Mean and SD were used for data analysis. The analysis results were brought to design the learning management model to promote growth mindset of student teachers in Step 2.

\subsection{Step 2: Model Design}

The researcher designed the learning management model to promote growth mindset of student teachers, with the key components, i.e., principles, goal, learning process, and assessment. Then, the model was brought to 5 experts with Ph.D. in learning management for student teachers; and with experiences in research on student teacher development. They examined the quality of the learning management model in terms of congruence, appropriateness, and feasibility.

The instrument for data collection to assess congruence, appropriateness, and feasibility of the model was a 5-rating scale assessment form with 12 questions. For the scoring criteria, 5 = highest, $4=$ high, $3=$ moderate, $2=$ low, $1=$ lowest. The reliability of the form was 0.80 . Mean and SD were used for data analysis. The analysis results were brought to improve the learning management model to promote growth mindset of student teachers.

After that, the learning management model was brought for a 10-hour pilot trial in 32 student teachers who were not the samples. They were obtained by 
voluntary selection. For the inclusion criterion, the volunteers must have interest in growth mindset development. For the exclusion criterion, the volunteers would be excluded from the research in case they participated in the learning activity less than $80 \%$ of the total time.

The instrument for data collection was a 5-rating scale assessment form with 20 questions. For the scoring criteria, $5=$ highest, $4=$ high, $3=$ moderate, $2=$ low, 1 = lowest. The reliability of the form was 0.87 .

The data was collected in the pre- and post-pilot trial phases. Students teachers were instructed to assess themselves. After data collection, the researcher analyzed the data by comparing pre- and post-pilot trial mean and SD values of growth mindset. The analysis results were brought to develop the learning management model again before trial in the samples in Step 3.

\subsection{Step 3: Model Trial}

The researcher conducted the trial of the learning management model in 134 samples of student teachers obtained by multi-stage sampling based on sample size calculation by $G^{*}$ Power. T-test was set at the effect size $f=0.50$, alpha err prob $=0.05$, and power $=0.95$. It was found that the sample size required must not less than 45 . Therefore, the samples in this trial of the learning management model were sufficient for analysis, conclusion, and generalizability. The trial took 4 months, with the inclusion criterion that the volunteers must have interest in growth mindset development. For the exclusion criterion, the volunteers would be excluded from the research in case they participated in the learning activity less than $80 \%$ of the total time. The instrument for data collection was the same assessment form as the pilot trial described in Step 2. Before data collection, the researcher notified student teachers that all answers would be kept confidential and would be analyzed as the overview of the research only. And no matter what their answers were, there would be no effects at all because they could be searched for any particular respondents. The samples also had right not to answer a question or even all of the questions if their answering caused frustration or discomfort.

The data was collected in the pre- and post-trial phases. Students' teachers were instructed to assess themselves. After data collection, the researcher analyzed the data by comparing pre- and post-trial mean and SD values of growth mindset. The analysis results were brought to assess effectiveness of the learning management model in accordance with the criteria in Phase 4.

\subsection{Step 4: Effectiveness Assessment}

The researcher assessed effectiveness of the learning management model in accordance with the criteria. To clarify, growth mindset of student teachers in the post-trial phase was higher than the pre-trial phase. T-test for dependent sample was used. Then, the learning management model was improver for perfection.

The 4 steps of research implementation can be summarized as in Figure 1. 


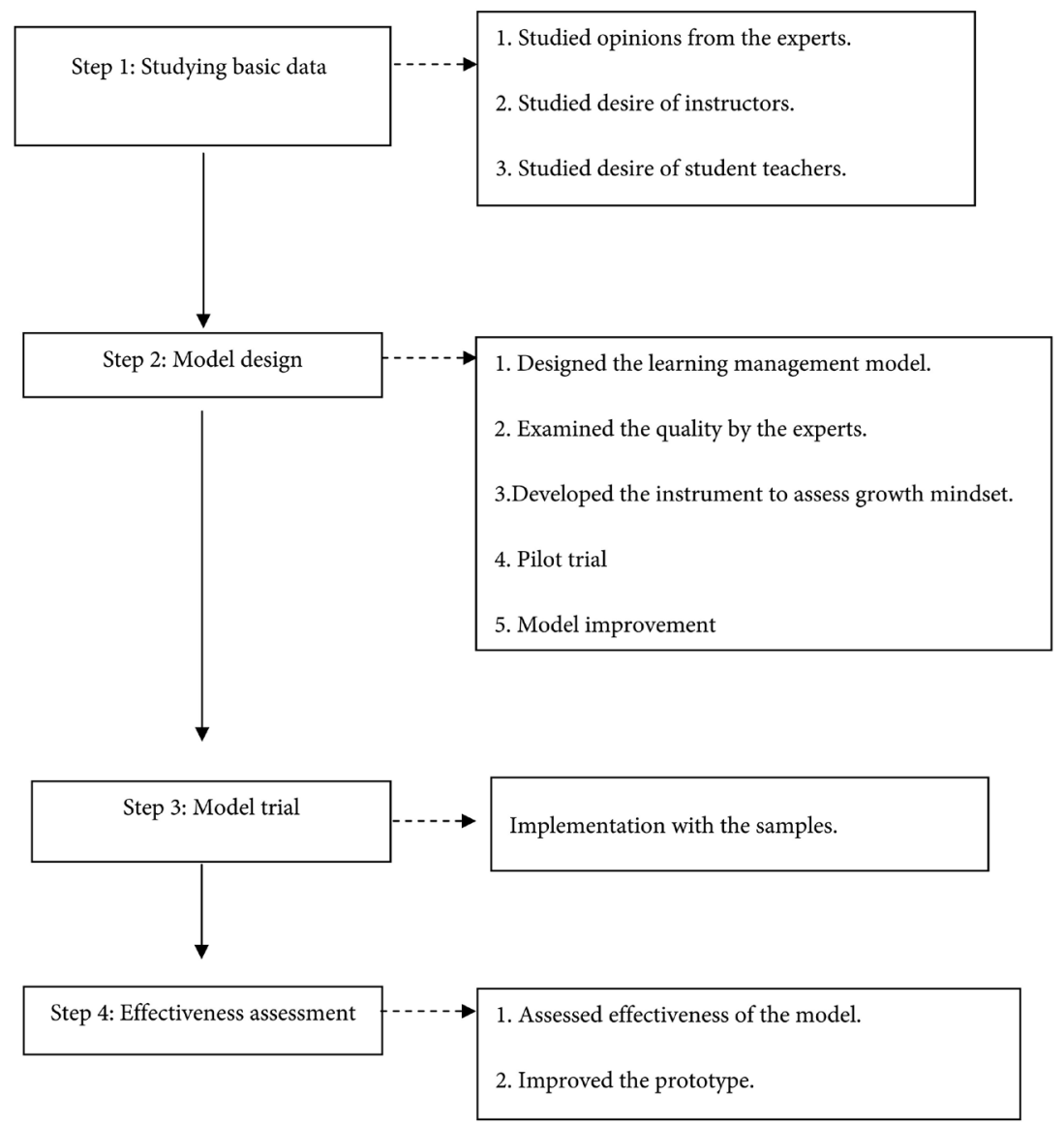

Figure 1. Research implementation process.

\section{Results}

\subsection{The Learning Management Model to Promote Growth Mindset of Student Teachers}

According to the research implementation, it was found that the learning management model to promote growth mindset of student teachers was based on personalized learning, self-directed learning, internal coaching, authentic assessment, and reflection. There were 5 components of learning management, i.e., learning ownership, creative learning design, creative learning activities, learning assessment, feedbacks; as in Figure 2.

Each component contained the details of learning management guidelines as follows.

\section{1) Learning Ownership}

Learning ownership is a basic principle for promoting growth mindset because it is the start of intrinsic motivation. When learners have such motivation, they will use self-efficacy at best for success. Then, learning ownership will occur through reflective thinking that all success is possible indeed if they use self-efficacy at best. This is called growth mindset. Therefore, instructors should provide an opportunity for learners to set their goals and learning approaches as much as they can. 


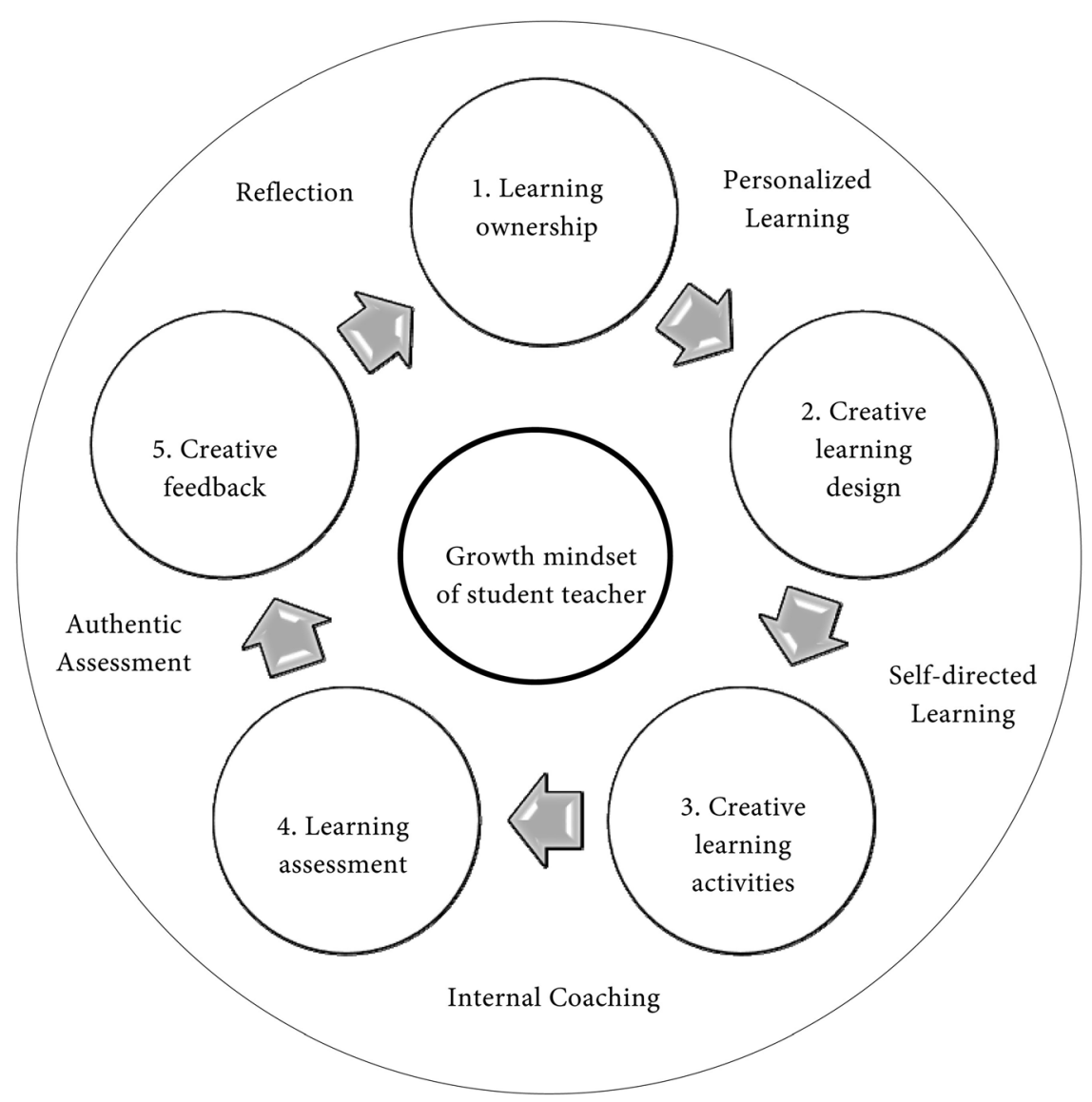

Figure 2. The theoretical learning management model to promote growth mindset of student teachers (Created by the authors).

\section{2) Creative learning design}

For creative learning design to promote growth mindset, instructors should design learning activities that conform to nature and interest of learners so that those activities will be challenging to learn. With those challenges, each learner can be successful while activities must be appropriate for the efficacy level of each learner. The characteristics of learning activities focus on collaborative learning rather than competitive because learners have more change to share knowledge with others. Therefore, they learn learning process of successful persons and adapt it. Instructors can also insert activities that encourage growth mindset to learners, along with learning activities, particularly reflective thinking to perceive their own learning progress in each phase of learning activities. No need to wait until after activities.

\section{3) Creative learning activities}

It is a learning process that helps promote growth mindset of learners, so-called mindfulness-based learning. Mindfulness leads to intellect, that is, to be aware that success is a result of learning and continual self-development. Furthermore, outcome-based learning process and mastery learning should also be focused, rather than outcomes only. Instructors create various learning processes, with alternatives of appropriate learning process for students. After 
various learning process designs, instructors should provide learners to do learning activities on their own in accordance with the process until the goals are achieved. Instructors promote and support learners to use their own learning process; and to give time to learners as planned, without skipping any steps. Be open-minded to facilitate learners to think and decide to choose their own learning process. Support them to turn creativity into practice so as to prove their thoughts. Instructors should also encourage learners to be determined for their success, along with knowledge sharing of learning process, problem-solving, showing determination to classmates or others. Promoting and supporting them for self-dependence is also required. Apart from these, instructors should provide various alternatives for success, depending on efficacy levels of learners so that all learners can be successful under the same learning outcomes. In case of failures or mistakes, instructors should not abandon ideas and opportunities for learners to learn from mistakes. They should let learners apply those mistakes to learning and better improvement by any other learning approaches, e.g., after action review (AAR) or reflective thinking.

\section{4) Learning assessment}

Learning assessment to promote growth mindset is based on authentic assessment as a tool to promote growth mindset. Information from assessment is used as the database to scaffold learners for their continual learning. The assessment mainly focuses on assessing efficiency of learning process and determination of learners rather than learning products only. It is an assessment that promotes learners to have growth mindset, focusing on assessment for learning rather than assessment for judgment. Besides, it can be used for self-assessment for learning in accordance with assessment as learning, too. To clarify, instructors provide an opportunity for self-assessment and self-reflection to make learners perceive that progress and success in learning has arisen from good learning process and determination; or that they should improve mistakes and keep developing their learning process. Instructors should also allow learners to create inner dialogues regularly so as to perceive usefulness and significance of growth mindset as it can promote growth mindset, too.

\section{5) Creative feedbacks}

Feedbacks are indispensable to develop learners for having growth mindset. Good feedbacks are information that can lead to changing thinking approaches and the development of learning process. Instructors should give feedbacks that connect with learning objectives. Those feedbacks should be specific, tangible, and useful for self-development of learners; and should focus on efficiency of learning process rather than learning products only. They should facilitate learners to make their own decision. Instructors should neither decide for learners nor put biases in given feedbacks. Motivation of learners should also be encouraged while giving feedbacks. They should also be encouraged that success is a result of determination. Instructors should also felicitate on success of learners.

The operational learning management model to promote growth mindset of student teachers is displayed in Figure 3. 


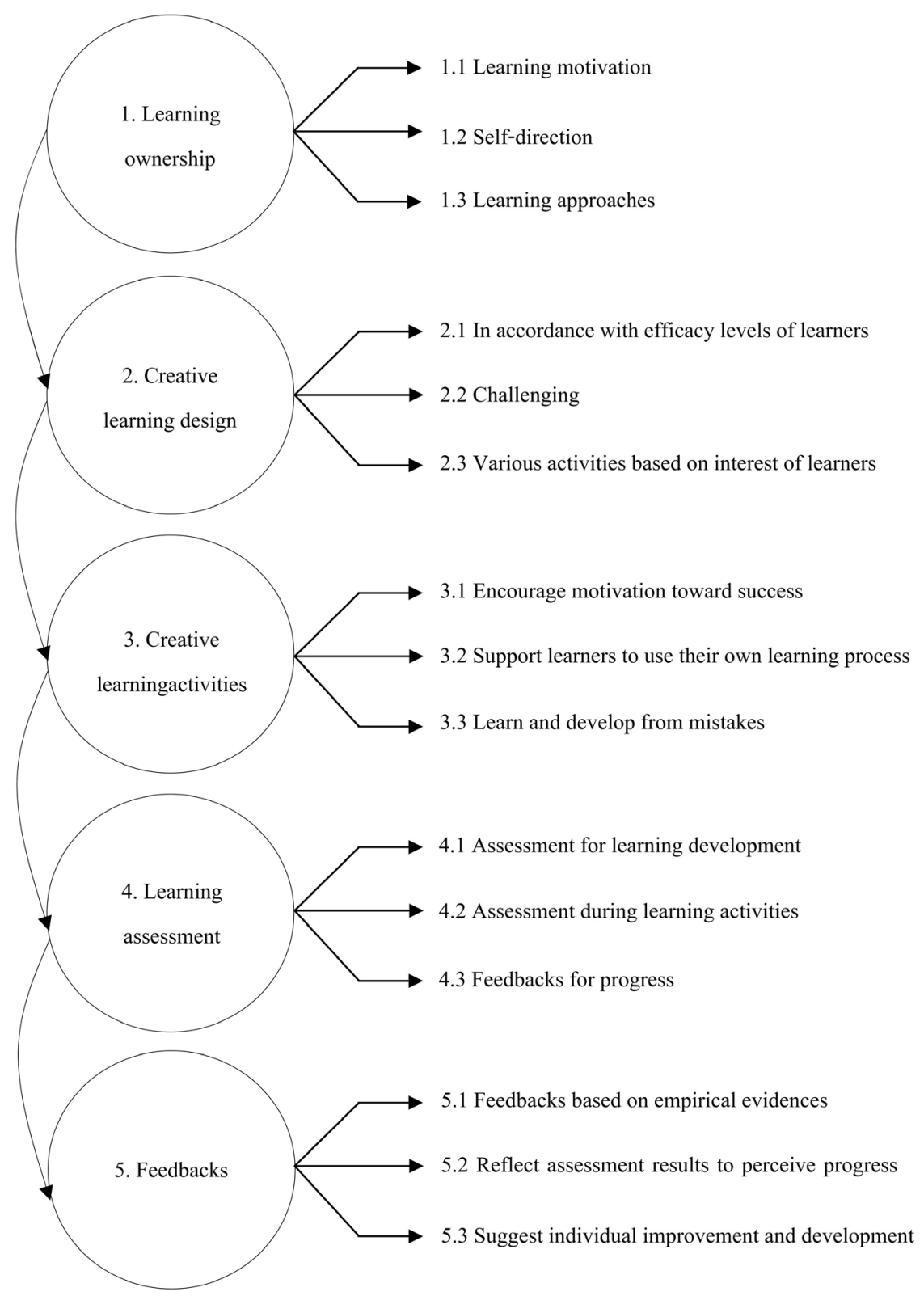

Figure 3. The operational learning management model to promote growth mindset of student teachers (Created by authors).

\subsection{The Results of the Assessment of Effectiveness of the Learning Management Model to Promote Growth Mindset of Student Teachers}

The results of compared growth mindset of student teachers between pre- and post-learning management model are displayed in the following Table 1.

Table 1 revealed that overall growth mindset of student teachers in pre-learning management model was moderate $(\bar{x}=2.81$, S.D. $=0.42)$. Growth mindset of student teachers in post-learning management model was high $(\bar{x}=4.11$, S.D. $=0.35$ ).

For the results of compared growth mindset of student teachers between pre- 
and post-learning management model by t-test for dependent sample, they are displayed in the following Table 2.

Table 2 revealed that growth mindset of student teachers in post-learning management was significantly higher than in pre-learning management $(p<$ $0.01)$.

The research results can summarize that the learning management model to promote growth mindset of student teachers composed of 5 elements such as 1) Learning Ownership is a basic principle for promoting growth mindset because it is the start of intrinsic motivation 2) Creative learning design for creative learning design to promote growth mindset, instructors should design learning activities that conform to nature and interest of learners so that those activities will be challenging to learn 3) Creative learning activities is a learning process that helps promote growth mindset of learners, so-called mindfulness-based learning 4) Learning assessment to promote growth mindset is based on authentic assessment as a tool to promote growth mindset and 5) Creative feedbacks is indispensable to develop learners for having growth mindset.

Table 1. Growth mindset of student teachers between pre- and post-learning management model (Full marks: 5).

\begin{tabular}{|c|c|c|c|c|c|c|c|}
\hline \multirow{2}{*}{ No. } & \multirow{2}{*}{ Items } & \multicolumn{2}{|c|}{ Pretest } & \multirow{2}{*}{ Interpretation } & \multicolumn{2}{|c|}{ Posttest } & \multirow{2}{*}{ Interpretation } \\
\hline & & $\bar{x}$ & S.D. & & $\bar{x}$ & S.D. & \\
\hline 1 & $\begin{array}{l}\text { Positive attitudes } \\
\text { toward themselves }\end{array}$ & 2.87 & 0.62 & Moderate & 3.99 & 0.40 & High \\
\hline 2 & Confident in self-efficacy & 2.74 & 0.46 & Moderate & 4.20 & 0.42 & High \\
\hline 3 & $\begin{array}{c}\text { Search for opportunities of } \\
\text { self-development }\end{array}$ & 2.82 & 0.38 & Moderate & 4.16 & 0.41 & High \\
\hline 4 & Learn new things regularly & 2.81 & 0.39 & Moderate & 4.14 & 0.35 & High \\
\hline 5 & $\begin{array}{l}\text { Be determined and } \\
\text { try to learn }\end{array}$ & 2.86 & 0.35 & Moderate & 4.07 & 0.35 & High \\
\hline 6 & Knowledge sharing & 2.76 & 0.43 & Moderate & 4.08 & 0.28 & High \\
\hline 7 & $\begin{array}{l}\text { Use various learning } \\
\text { approaches }\end{array}$ & 2.85 & 0.36 & Moderate & 4.10 & 0.31 & High \\
\hline 8 & $\begin{array}{l}\text { Reflective thinking for } \\
\text { self-development }\end{array}$ & 2.80 & 0.40 & Moderate & 4.13 & 0.33 & High \\
\hline 9 & $\begin{array}{l}\text { Continual/regular } \\
\text { self-development }\end{array}$ & 2.78 & 0.42 & Moderate & 4.15 & 0.36 & High \\
\hline 10 & Suggest others to learn & 2.86 & 0.35 & Moderate & 4.08 & 0.28 & High \\
\hline & Total & 2.81 & 0.42 & Moderate & 4.11 & 0.35 & High \\
\hline
\end{tabular}

Table 2. Comparing growth mindset pre-test and post-test.

\begin{tabular}{cccccc}
\hline Testing & $\bar{x}$ & S.D. & $t$ & $\mathrm{df}$ & $p$-value \\
\hline Pretest & 28.14 & 1.34 & & & 0.000 \\
Posttest & 41.11 & 1.31 & 83.90 & 133 & \\
\hline
\end{tabular}




\section{Discussion}

The results revealed significant growth mindset of student teachers in post-learning management model $(p<0.01)$ because the instructional activity in the form of the learning management model could motivate learning for learners. Their learning motivation facilitated growth mindset development. This conformed to the results of the research of Rhew, Piro, Goolkasian, \& Cosentino (2018) and Cacali (2019). Another key factor was instructors with growth mindset, which affected promoting growth mindset of student teachers likewise. Growth mindset of instructors affected learning management behavior, which affected learning experience of student teachers later on; as stated by Hoffer (2016). This conformed to Rienzo, Rolfe, \& Wilkinson (2015), stating that learners who studied with instructors with growth mindset had better achievements than those studying with instructors whose growth mindset was not developed. Similarly, Goldberg (2016) stated that if instructors had 4 beliefs in learners, i.e., 1) all learners had values and should be praised, 2) all learners could learn through different learning approaches, 3) all learners could learn and be successful, and 4) all learners had efficiency of self-development to success; these beliefs would definitely affect learning management to promote growth mindset of student teachers.

Apart from growth mindset of instructors that affected growth mindset of student teachers, quality learning management behavior of instructors also helped develop growth mindset of student teachers, i.e., open mind; listening; always searching for new ideas; creatively communicating learning progress of learners to their parents; inventing new learning approaches for best learning; promoting learners to have a chance for learning success; learning and development from fellows of the same field and different fields; improvement and development for best learning and for the most appropriateness; motivating learning inspiration and self-development; and building confidence that learners could learn and be successful. This conformed to the statements of Hanover Research (2015) and Brock \& Hundley (2016).

Promotion, support, assistance, and scaffolding for learning; including power questions, cognitive guided, knowledge sharing, and promoting learners to show their best self-efficacy also increased growth mindset of student teachers. This conformed to Dweck, Walton, \& Cohen (2014), stating accordingly. Confidence in self-efficacy was also motivated, along with their motivated self-value, self-esteem, and an idea/belief that efficacy in different skills could be developed through determination and effort. This conformed to the academic articles and the results of the research of Dockterman \& Blackwell (2014), Hanover Research (2015), Illinois Center for School Improvement (2016), Silver \& Stafford (2017), Liu, Robinson, \& Xu (2018), Ronkainen, Kuusisto, \& Tirri (2019), Lee, Ryu, \& Gu (2020), Leigha (2020), and Wechtaisong, Phaikoksong, \& Hiranchiracheep (2020). These were the key components to develop growth mindset of student teachers in this research. 


\section{Conclusion}

Growth mindset of learners could be promoted and developed by instructors. Specifically, instructors had growth mindset first. This led to design of learning with learning ownership. Learning management was conducted, of which learning process was focused; along with assessment that focused on learning process and determination of learners. Instructors also encouraged learners to believe that everything could be achieved if the goals were clear, with good learning process and determination.

To apply the learning management model obtained from this research, the nature of each individual student teacher should be analyzed. Then, learning should be managed step by step in accordance with the learning management model based on each student teacher as aforementioned. Instructors should promote and support learners to use their own thinking as well as learning process. Their self-assessment and self-reflection should also be encouraged continually. The limitation in this research was the sample size of student teachers, which might be small; and thus, it possibly affected the stability of the developed learning management model. However, those who are interested to apply this model can adapt it in accordance with contexts and situations.

\section{Conflicts of Interest}

The authors declare no conflicts of interest regarding the publication of this paper.

\section{References}

Alerson, L. (2017). Growth Mindset: The Door to Achieving More. https://www.free-ebooks.net/ebook/Growth-Mindset-The-Door-to-Achieving-More/p df?dl\&preview

Blackwell, S., Trzesniewski, H., \& Dweck, C. (2007). Implicit Theories of Intelligence Predict Achievement across an Adolescent Transition: A Longitudinal Study and an Intervention. Child Development, 78, 246-263.

https://doi.org/10.1111/j.1467-8624.2007.00995.x

Brandman University (2019). The Importance of Adopting a Growth Mindset in Your Teaching.

https://www.brandman.edu/news-and-events/blog/the-importance-of-adopting-a-gro wth-mindset-in-your-classroom

Brock, A., \& Hundley, H. (2016). The Growth Mindset Coach: A Teacher's Month-By Month Handbook for Empowering Students to Achieve. Berkeley, CA: Ulysses Press.

Cacali, E. (2019). The Effects of Growth Mindsets on University EFL Motivation in Japan. Kwansei Gakuin University Humanities Review, 23, 125-132.

Clark, A., \& Sousa, B. (2018). How to Be a Happy Academic. Thousand Oaks, CA: SAGE Publications Inc.

Dockterman, D., \& Blackwell, L. (2014). Growth Mindset in Context Content and Culture Matter Too. International Center for Leadership in Education. http://daggett.com/pdf/GrowthMindset.pdf

Dweck, C. (2006). Mindset: The New Psychology of Success: How We Can Learn to Fulfill 
our Potential. New York: Ballantine.

Dweck, C. (2008). Mindset. New York: Ballantine Books.

Dweck, C. (2009). Who Will the 21st Century Learners Be? Knowledge Quest, 38, 8-9.

Dweck, C. (2012). Mindset: How You Can Fulfill Your Potential. London: Robinson.

Dweck, C., Walton, G., \& Cohen, G. (2014). Academic Tenacity: Mindset and Skills That Promote Long-Term Learning. Seattle, WA: Bill \& Melinda Gates Foundation.

Education Week Research Center (2016). Mindset in the Classroom: A National Study of K-12 Teachers. Bethesda, MD: Editorial Projects in Education Inc.

Flores, D., Lemons, A., \& McTernan, H. (2011). The Correlation between Student Growth Mindset and Conceptual Development in Physics. Action Research Required the Master of Natural Science with Concentration in Physics, Arizona University.

Goldberg, G. (2016). Mindset \& Moves: Strategies That Help Readers Take Charge. Thousand Oaks, CA: Corwin.

Good, C., Anderson, J., \& Inzlicht, M. (2003). Improving Adolescents' Standardized Test Performance: An Intervention to Reduce the Effect of Stereotype Threat. Journal of Applied Development Psychology, 24, 645-662.

https://doi.org/10.1016/j.appdev.2003.09.002

Grant, H., \& Dweck, C. (2003). Clarifying Achievement Goals and Their Impact. Journal of Personality and Social Psychology, 85, 541-553.

https://doi.org/10.1037/0022-3514.85.3.541

Gregory, G., \& Kaufeldt, M. (2015). The Motivated Brain: Improving Student Attention, Engagement, and Perseverance. Alexandria, VA: ASCD.

Gunn, J. (2020). Building a Growth Mindset for Teachers. https://resilienteducator.com/classroom-resources/growth-mindset-for-teachers

Hanover Research (2015). Strategies for Promoting Student Growth Mindset. Arlington, VA: Hanover Research Corporate Headquarters.

Herbert-Smith, K. (2018). Growth Mindset: The Key to Successful Teaching? https://blog.irisconnect.com/uk/community/blog/5-attributes-of-a-growth-mindset-tea cher

High Point University (2016). QEP Report Developing a Growth Mindset. http://www.highpoint.edu/qep/files/2016/03/HPU-QEP-2016_print-2-24-2016.pdf

Hildrew, C. (2018). Becoming Mindset School: The Powerful of Mindset to Transform Teaching, Leadership and Learning. New York: Routledge. https://doi.org/10.4324/9781315179506

Hoffer, W. (2016). Cultivating STEM Identities: Strengthening Student and Teacher Mindsets in Math and Science. Portsmouth, NH: Heinemann.

Illinois Center for School Improvement (2016). Habits of Mind-Developing a Growth Mindset. Material for the Illinois Center for School Improvement, a Partnership between the Illinois State Board of Educational and American Institute for Research, are Federally Funded Unless Otherwise Noted.

Lee, C. S., Ryu, E. K., \& Gu, H. J. (2020). The Effects of Growth Mindset and Self-Directed Learning on Organizational Effectiveness of Workers: The Moderated Mediation Effect of Grit. International Journal of Advanced Science and Technology, 29, 155-162.

Leigha, R. (2020). The Effect of Instructor Mindset on Student Motivation and Self-Efficacy. https://augusta.openrepository.com/handle/10675.2/623439

Liu, Y., Robinson, M. N., \& Xu, H. (2018). The Effect of Mindset on Students' Desire to Work for Big Four Accounting Firms and on Academic Performance. E-Journal of 
Business Education \& Scholarship of Teaching, 12, 92-106.

Millersville University (2020). Teaching with a Growth Mindset. https://www.millersville.edu/cae/teaching-and-learning/teaching-growth-mindset.php

Mueller, C., \& Dweck, C. (1998). Praise for Intelligence Can Undermine Children's Motivation and Performance. Journal of Personality and Social Psychology, 75, 33-52. https://doi.org/10.1037/0022-3514.75.1.33

Ng, B. (2018). The Neuroscience of Growth Mindset and Intrinsic Motivation. Brain Sciences, 8 , 20. https://doi.org/10.3390/brainsci8020020

Rhew, E., Piro, J. S., Goolkasian, P., \& Cosentino, P. (2018). The Effects of a Growth Mindset on Self-Efficacy and Motivation. Curriculum \& Teaching Studies, 5, Article ID: 1492337. https://doi.org/10.1080/2331186X.2018.1492337

Rienzo, C., Rolfe, H., \& Wilkinson, D. (2015). Changing Mindsets: Evaluation Report and Executive Summary. London: National Institute of Economic and Social Research.

Ronkainen, R., Kuusisto, E., \& Tirri, K. (2019). Growth Mindset in Teaching: A Case Study of a Finnish Elementary School Teacher. International Journal of Learning, Teaching and Educational Research, 18, 141-154. https://doi.org/10.26803/ijlter.18.8.9

Schroder, H., Moran, T., Donnellan, M., \& Moser, J. (2014). Mindset Induction Effects on Cognitive Control: A Neurobehavioral Investigation. Biological Psychology, 103, 27-37. https://doi.org/10.1016/j.biopsycho.2014.08.004

Silver, D., \& Stafford, D. (2017). Teaching Kids to Thrive: Essential Skills for Success. Thousand Oaks, CA: A SAGE Company. https://doi.org/10.4135/9781506374413

Smith, M., \& Firth, J. (2018). Psychology in the Classroom: A Teacher's Guide to What Works. Oxon: Routledge. https://doi.org/10.4324/9781315163420

Stager, P. (2015). The Power of Growth Mindset. The Direct Support Workers Newsletter, 4, 1-7.

Wechtaisong, C., Phaikoksong, S., \& Hiranchiracheep, S. (2020). The Study of the Effects of the Growth Mindset Program in Engineering Classroom. Journal of Research \& Method in Education, 10, 36-41. https://doi.org/10.1155/2020/8067619

Weiss, D., \& Fortus, D. (2013). School, Teacher, Peers, and Parents' Goals Emphases and Adolescents' Motivation to Learn Science in and out of School. Journal of Research in Science Teaching, 50, 952-988. https://doi.org/10.1002/tea.21103

Yeager, D., \& Dweck, C. (2012). Mindsets That Promote Resilience: When Students Believe That Personal Characteristics Can Be Develop. Educational Psychologist, 47, 302-314. https://doi.org/10.1080/00461520.2012.722805 